\title{
Preventive strategies to combat infections-a review of traditional practices and Ayurveda concepts
}

\begin{abstract}
India is the land of traditions and religious beliefs that stand proudly next to the global technology. The great sages of India chanted shantih mantra and its echoes have reverberated through centuries. The quest for happiness and success has been the dynamic factor in the course of evolutionary history. It is reflected in Brihadaranyaka Upanishad, which conveys that "May all be free from illness/ disease" which speaks about Universal health. Ayurveda advocates several non-pharmacological measures that are critical to overall health, including diet, sleep, mental factors, and environmental hygiene. There is a need to decode some of the non pharmacological, prophylactic measures that might sound superstitious to many, but are age-old practices of our ancestors and widely followed. This paper highlights prophylaxis aspects practiced traditionally in different parts of India along with Ayurvedic views and rationale behind these practices. Many age-old practices widely followed by our ancestors to prevent infectious diseases like daily regimens, seasonal regimens, personal hygiene, environmental hygiene, dietary guidelines, immunity boosting measures are relevant even today.
\end{abstract}

Volume I 3 Issue 3 - 2020

\author{
Shubhashree MN, Raghavendra Naik, \\ Shashidhar H Doddamani, Bhavya BM \\ Research Officer(Ayu), Regional Ayurveda Research Institute for \\ Metabolic disorders, India

\begin{abstract}
Correspondence: Shubhashree M.N, Regional Ayurveda Research Institute for Metabolic disorders (RARIMD), \#I2, $(\mathrm{Tq})$, Kanakapura main road, Talaghattapura post, Bengaluru -560109 Karnataka, India, Tel 9448016968 ,
\end{abstract} \\ Uttarahalli Manavarthekaval,Uttarahalli (Hobli), Bangalore South \\ Email shubhathejs@gmail.com
}

Received: June 02, 2020 | Published: June 22, 2020

Keywords: Ayurveda, COVID-19, prophylaxis, preventive

\section{Introduction}

The healthcare system around the world has been posed with an unprecedented challenge by the pandemic Covid 19. In the absence of known medicines and vaccines for this condition, the whole world is looking for preventive strategies and additional remedies from different traditional systems of medicines including Ayurveda. A number of research findings are also pouring in from all sides to improve the immunity from the attack of this virus. The need of the hour is to protect ourselves from this deadly disease. Ayurveda is a traditional system of medicine originated in the ancient Vedic times of India. It is a comprehensive approach to health and homeostasis that addresses body, mind, emotions, spirit, and environment. ${ }^{1}$ It has emphasized on personal hygiene, social hygiene and environmental hygiene. One of the oldest treatises of Ayurveda, Charaka Samhitha has elaborately described about dealing with pandemics, as "Janapadodwamsa" caused by polluting air, water or land. He further explains the role of Vayu (air), aapa (Water), Desha (soil \& area), Kala (Time) are the factors responsible for Janapadodhwansha i.e epidemics. Charaka's description is more of the infectious disease, and narrates contamination of physical, chemical \& biological factors in occurrence of disease. ${ }^{2,3}$ Here is an attempt to decode some of the practices that might sound superstitious to many, but are age-old practices of our ancestors and widely followed.

\section{Concept and understanding of infectious condition in Ayurveda}

In Ayurveda, Communicable disease is classified into contagious disease (where the spread is usually by direct contact) and infectious diseases (one which is liable to be transmitted to people, organisms, etc. through the environment). Acharya Sushrutha, who is also known as father of ancient surgery has described the diseases like Jwara (Fever), Shosha (Tuberculosis), Kushta (Skin diseases) are contagious and spreads through direct contact or through contaminated objects. ${ }^{4}$
It is described as Aupsargika roga i.e. contagious disease or spread of disease through contacts. The causative factors for infectious conditions like fevers, conjunctivitis, common cold, etc are also enumerated as due to sexual intercourse, physical touch, respiration, exchange of body-fluids, sleeping on the same bed, sitting neck to neck, eating together from a common plate, or eating somebody's leftovers, sharing clothes, ornaments, unguents (soap, lotions etc). It is mentioned that in certain conditions like spider bite or poisoning leading to infections, it requires 21days (of quarantine measure) as it is self limiting. ${ }^{5}$ In yet another context of Vrana (ulcer), as mentioned in the treatise Sushrutha Samhitha, written by Acharya Sushruta estimated to be written during $1000 \mathrm{BC}$, he mentions the infectious conditions and preventive measures to be taken in the chapter Shasti upakrama $^{6}$ (wound/ulcer management). A patient with a wound or ulcer, may end up in dusthavrana (non healing ulcer) if he is not clean and disciplined. The signs and symptoms of an infected wound with discharge are explained with the remedial measures. Fumigation was used for the purpose of elimination of any remnant infections from the site as well as to prevent the subsequent contamination of the created clean wound. Dhupana (fumigation) is one of the unique methods mentioned for the removal of Krimi (microorganisms) with various bacteriostatic drugs like Guggulu, Vacha, Haridra etc. This measure of Vrana Dhupana destroys the growth of microorganisms at the wound site and thus accelerates the process of healing. Though, there is no mention of virus or bacterial infections, these measures are practical and significant even today and gives us an insight that role of microorganism and knowledge of epidemics was known to Ayurveda.?

Ayurveda advocates the principle of Pratyaksha (Direct observation), Anumana (Inference) Aptopadesha (Textual reference) and Yukthi (Logic) in understanding the visible and invisible things. ${ }^{8}$ The signs and symptoms can be directly observed or known from the patient, however, in some conditions, based on the signs and symptoms, the causative factors are inferred as it happens with viral 
infections. Sometimes, the rich knowledge stored as texts give us the idea about the illness and diagnosis and at times, it is entirely dependent on logical thinking. Yet, Ayurveda has emphasized more on body's response and occurrence of disease occurs only if the Bala (Body immunity) is reduced.

\section{Measures to prevent infectious condition as described in Ayurvedic classics}

Ayurveda has depicted various rules and regimens (Charya), regarding diet and behavior to acclimatize seasonal enforcement easily without altering body homeostasis. The main objective of Ayurveda is Swasthyasya Swasthya Rakshanam, which means maintenance of the healthy status, rather than Aturashya Vikara Prashamanam, (cure the diseases of the diseased) ${ }^{9}$. According to Ayurveda, combating these infectious diseases has to be done at various stages like stopping the progression, building immunity against diseases using various measures. ${ }^{3}$ Stopping the progression of the disease in case of communicable disease is the most ideal stage of controlling the disease, moreover increasing immunity by various means against these ailments are also required. ${ }^{3}$ This is exactly the whole world is doing in the context of Covid 19.

There are daily regimens mentioned like Nasya (instillation of medicated drops) into the nose and Kavala Gandusha (gargling of mouth), all of which appear trivial, yet effective in maintaining nasal and oral hygiene. The more recent understanding of neuro endocrine immune axis or the influence of exercise, circadian rhythms, seasonal variations, different psychological states on immune system are unfolding many such issues which are bringing the modern concept closer to Ayurvedic principles. ${ }^{10}$ The eyes, nose, and mouth are the main entry points which carry droplets infection. In Ayurveda, it is mentioned as Naso hi shirasi dwaram(which implies that nose is the entry point for the head and upper part of the body). It is a known fact that the fatty acid coat of the virus adheres to the moist mucosal layers, which helps it gain entry into the cells by binding to specific cell receptors. Ayurveda classics mention several measures which block these entry portals and may help to improve the innate immunologic response of the mucus membranes and may thus inhibit the virus transmission to the lungs and these measures may hence function as "physiological masks" barricading the viral invasion. ${ }^{11}$

\section{Dinacharya}

Classical texts of Ayurveda have detailed rituals or practices that one should follow every day to establish the balance of body humors, which helps to regulate a person's biological clock and synchronize us to nature's circadian rhythms. Dinacharya is known as the ideal life style which explains various duties one has to follow in a day to maintain a healthy life. These are the duties systematically and scientifically explained to establish balance in one's body constitution. It also regularizes a person's biological clock, aids digestion, absorption and assimilation and generates self esteem, discipline, peace, happiness and longevity. It starts from waking up in the morning in Bhramhi muhurtha(early morning before sunrise), Ushapana(drinking water stored in copper or silver pot), Mala-Mutra Visarjana( Defeacation), Dantadavana(brushing), Kavala Gandusha (gargling)etc. Starting from the benefits of trimming the nails, taking bath, using a footwear, using umbrella to protect from strong sunrays, every do's and dont's are described in detail in the context of Dinacharya (Daily regimen) ${ }^{12}$. For instance, Ayurveda recommends storage of water in copper vessels. Interestingly, the antibacterial effect of copper pot against important diarrhoeagenic bacteria, including Vibrio cholerae O1, Shigella flexneri 2a, enterotoxigenic Escherichia coli, enteropathogenic E. coli, Salmonella enterica Typhi, and Salmonella Paratyphi is reported. The studies have shown that the copper ions brought about complete killing of bacteria by membrane damage .As availability of pure water is still a major concern in many of the developing countries Copper holds promise as a point-of-use solution for microbial purification of drinking-water. ${ }^{13}$

\section{Rutucharya}

Ancient sages set up the regimen for various seasons on analytical reasoning to maintain health and prevent the diseases. Ayurveda has depicted various rules and regimens (Charya), regarding diet and behavior to acclimatize seasonal enforcement easily without altering body homeostasis. ${ }^{14}$ The prime principle of Ayurvedic system of medicine is preventive aspect, can be achieved by the change in diet and practices in response to change in climatic condition. This is a very important aspect of preventive medicine as mentioned in Ayurvedic texts. With the change in season, the change is very evident in the environment we live in. As human being is also part of the same ecology, the body is greatly influenced by external environment. Many of the exogenous and endogenous rhythm have specific phase relationship with each other; which means that they interact and synchronize each other ${ }^{15}$. If body is unable to adopt itself to stressors due to changes in specific traits of seasons, it may lead to one or other kinds of disorders. The stress of coping with energetically demanding conditions can also indirectly cause illness and death by compromising immune function. ${ }^{16}$

\section{Personal hygiene}

Interestingly, Indian tradition emphasizes on washing the hands and feet as soon as one enters from outside the house and also before consuming food, which has become an essential norm to prevent infection these days. The same has been quoted in Sushrutha samhitha. ${ }^{17}$ It has been advised to wear washed clean clothes after taking bath. Usage of towels or clothes used by others is also forbidden. It has also been advised to wear different clothes while going out and while going to sleep. It has been repeatedly mentioned in puranas not to wear wet clothes or clothes belonging to others. Those attending funeral or haircut should compulsorily take bath immediately after return. Though these measures have been described about five thousand years back, it is relevant till date. Drinking water without touching the lips to the container, non sharing of plates, appear to be practices of uncivilized society, yet contribute a lot to the prevention of infection. Offering prayers after bath, maintaining distance to have purity of thoughts (mind) and body, is a tradition followed in India. It was once dubbed as superstitious discrimination and it is welcomed as hygiene measure now

\section{Environmental hygiene}

The health of an individual's residing place is always influenced by the environmental changes. Widespread manifestation of diseases occurs due to lack of environmental hygiene. Environmental hygiene means the healthful environment of man; it deals with mainly external environment like water, air, land etc. In Ayurveda external environment like Jala, Vayu, Bhumi and Kala has been explained in relation to health and disease. A study reported that, absence of pathogenic bacteria Coryne bacterium urea lyticum, Curto bacterium flaccumfaciens, Entero bacter aerogenes (Klebsiella mobilis), Kocuria rosea, Pseudomonas syringae pv. persicae, Staphylococcus lentus, and Xanthomonas campestris pv. tardicrescens in the open room even after 30 days is indicative of the bactericidal potential of the medicinal 
smoke treatment. ${ }^{18}$ The purification methods mentioned in Ayurveda for water, air and soil are may be crude and useful in domestic level in rural area still have scientific basis, these can be propagated through mass media to reach even in urban area.

\section{Role of diet}

The curative effect of food is an established belief for many generations in India. Indian culture has strongly suggested the role of diet in both preventive and therapeutic medicines. These Indian traditional foods are based on the different indigenous systems of medicine which was the natural way of achieving physical and mental wellness, but their origin still remains unknown. Though, the whole world realized that food plays a major role in disease prevention only in the $20^{\text {th }}$ century, ancient India seems to have realized the importance of food in health and wellness much ahead of time. Rasam, a soup of spices, is a traditional South Indian food. It is traditionally prepared using tamarind juice as a base, with the addition of Indian sesame oil, turmeric, tomato, chili pepper, pepper, garlic, cumin, curry leaves, mustard, coriander, asafoetida, sea salt, and water. Rasam is a classic example of traditional functional food with all its ingredients medicinally claimed for various ailments. The systematic consumption of such traditional functional food provides an excellent preventive measure to ward off many diseases. Tribal families of some parts of India, consume rasam for the treatment of fever, common cold, and diarrhea. ${ }^{19}$ Most of the south Indian population consume Rasam regularly which is traditionally used for the treatment of cold, cough, and diabetes.

In India, several spices used for daily consumption are said to posess antiviral properties. Hence, there is a realistic possibility to reach a therapeutic dose by daily dietary consumption. There are many drugs mentioned in Ayurveda which are used in the kitchen as food for daily consumption like Turmeric, asafoetida, and garlic which have antimicrobial activities. Published records reveal that traditional Chinese herbal medicine combined with western medicine treatment regimen has reduced adverse events as well as reduced recovery time.

Turmeric is widely used as food in India as well as a medicine in Ayurveda system of Medicine. It is estimated that an adult in India consumes $80-200 \mathrm{mg} /$ day of curcumin, the bioactive component of turmeric, and $50 \mathrm{~g}$ of garlic in a week. ${ }^{19}$ It has an alkaloid known as curcumin which has demonstrated a wide range of antiviral activity against different viruses. Curcumin showed the anti-influenza activity against influenza viruses PR8, H1N1, and H6N $1 .{ }^{20}$ Curcumin is said to inhibit Zika and chikungunya virus replication in human cells and acts at an early step in virus infection. The virus incubated with curcumin loses infectivity as it interferes with virus-cell binding. ${ }^{21}$ Similarly, Garlic is one of the ancient herbal remedies used in human history. Fresh garlic extract with allicin as the main active component of it has been shown to have antiviral activity in vitro and in vivo. Its beneficial effects are attributed to sulfur-containing compounds such as allicine, diallyl disulfide, diallyl trisulfide. ${ }^{22}$ Ginger (Zingiber officinale, Zingiberaceae) is also known as Vishwabheshaja (Universal medicine), Mahaushadha (best medicine) in Ayurveda. ${ }^{23}$ It has been widely used as a dietary spice, and as a traditional oriental drug. It is also reported that, some compounds of Zingiber officinale considered to be inhibit the viral replication inside the HCV-infected HepG2 cells. ${ }^{24}$

Onion and garlic are natural sources which are known to possess antiviral properties. It is well known that onion and garlic are rich source of organosulfur compounds. Organosulfur compounds like quercetin and allicin are associated with inhibition of viral infection.
These chemicals can hinder virus attachment to host cell, alter transcription and translation of viral genome in host cell and also affect viral assembly. Quercetin can affect entry and attachment of Enterovirus and Influenza virus on host cell. This compound also has ability to inhibit RNA polymerase which is necessary for viral replication. Quercetin also inhibit process by which virus alter signalling pathway in host cell. It is known that allicin can pass through phospholipid membrane of cell and can further contribute in inhibiting viral multiplication. ${ }^{25}$

\section{Importance of hot water}

Hot water and its benefits have been highlighted more during Covid 19. Ayurveda always emphasizes on medicinal properties of hot water as promotes digestion, relieves throat pain, clears phlegm and generally it is recommended for drink in condition of throat infection. It is specially mentioned as Kantya. ${ }^{26}$ In the advisory, the Ministry of AYUSH (Ayurveda, Yoga, Unani Siddha, Homeopathy in India), Government of India has prescribed Immuno modulatory Ayurvedic drugs as a preventive measure against COVID-19 disease along with other measures like using hotwater and tea made out of pepper, ginger, tulsi (Basil leaves) ${ }^{27}$. Ayurveda also advocates this as a measure for improving digestion of Ama, a proinflammatory product of impaired metabolic disorders. The presence of Ama is linked to increased susceptibility to infections. Traditionally, warm water is consumed in many parts of India for diverse disorders of fever, inflammation, metabolism, and allergy such as rhinitis and asthma. ${ }^{11}$ Several spices that are popularly used in the kitchen are added as single or multiple agents to the boiling water and consumed as medication throughout the day.

\section{Concept of immunity and immunomodulation}

Ayurveda compares the concept of healthy body to a barren land. Just as a barren land cannot bear fruits or flowers, similarly healthy body cannot favour infectious conditions. Flowering depends on factors like right timing, fertile land, good quality of seed .Similarly, the infections can develop when the body immunity is low, infectious agent is strong and time refers to the depleted bala(immunity) stage. ${ }^{28}$

The basic concept of immunomodulation not only existed in Ayurveda but is being really practiced by the Ayurvedists for centuries. Body immunity cannot be enhanced overnight. Daily regimen, dietary intake contributes to immunity. In fact, Ayurveda has always emphasized on enhancing the body's overall natural resistance to the disease causing agent rather than directly neutralizing the agent itself. Interestingly, body immunity is understood as Sahajabala or natural immunity (genetic and inborn resistance) Kalajabala -seasonal or age related and Yuktikrutabala (Modulated by diet, exercise, regimen and immunomodulators -rasayanas). ${ }^{29}$ Body immunity (Host factor) is given the utmost importance and the methods to strength host immunity like following Dinacharya (Daily regimen) and Rutucharya (Seasonal regimen) are emphasized in Ayurveda. The interventions include therapeutic cleansing procedures (Panchakarma) and certain immunomodulators (Rasayana). The choice of specific Ayurvedic therapeutic agents and practices is based on certain individual genetic characteristics known as Dosha Prakriti types (Vata, Pitta, and Kapha).

\section{Potential immunomodulators mentioned in Ayurveda}

According to Ayurveda when immunity becomes weak, the virus and bacteria can develop and multiply in the body. One's immune 
system must be boosted so that the body can fight against bacteria and virus and prevent diseases. The agents that improve Quality Of Life, provide strength or resistance against the disease and also facilitate early recovery are classified under General Health Promoters. The drugs/formulations having Balya (Tonic), Rasayana (Immunomodulator) etc properties can be considered under this group.

Ayurveda boasts of many medicinal plants which can enhance body immunity like Ashwagandha (Withania sominifera), Guduchi (Tinospora cordifolia) etc . Some studies reported that, Ashwagandha may be effective in improving host immunity through the modulation of key targets relevant to COVID-19. It is also reported that, clinical effects of Ashwagandha containing Ayurvedic formulation to be equivalent to HCQ in a RCT for treating rheumatoid arthritis. It depicts potential mechanisms of action of Ashwagandha in prophylaxis (antiviral, immune boosting, vascular integrity) and management (pyrexia, anti-inflammatory, conserving alveoli) related clinical targets of COVID-19. Ashwagandha formulations may be effective as a prophylactic and adjunct treatment of COVID-19. It can offer multi-target effects in inflammatory conditions by restoring immune homeostasis. Further research studies can also be planned to determine the clinical efficacy of Rasayana drugs such as Ashwagandha, Guduchi, Amalaki, and Yashtimadhu. ${ }^{11}$

\section{Traditional recipes followed in different parts of India}

Some traditional Dietary and medicinal preparations are being used in various parts of India to reduce the chances of infectious diseases. Oushadha Kanji is one of the unique medicinal porridge consumed in the South Indian states during the rainy season which is popular as traditional drink consumed in July and August. This is a special diet based on the principles of Ayurveda which is good for the people of all age groups as it would help to improve the immunity of the body and acts as a detoxifying agent. The unique combination of herbs, spices and rice in this dish is expected to keep monsoon fevers at bay and have a positive effect against some of the common diseases of rainy season. It contains Caraway seed, Fenugreek seeds, Cardamom, Cumin seeds, Coriander seeds, Aniseed, Dry Ginger, Black Cumin, Cloves, Dried Turmeric , Common sida/Common Wireweed .This combination is made in the form of gruel/porridge using rice, greengram and consumed. ${ }^{30}$ Similarly, beverage made up of coriander seeds, cumin seeds, pepper, fennel/saunf, cardamom, clove, turmeric , ginger powder are used along with milk and jaggery in some parts of south India.

Likewise, in summer, in southern states of India like Kerala, warm, coloured water is served which is known as Karingal vellam. It is prepared with water infused with herbs and roots. After sumptuous meal, it would be ginger infused water or Cumin seeds. The practice of consuming warm water ensures that it is made safe for consumption with boiling.

There are instances of particular communities administering decoction of Saptaparna (Alstonia scholaris) in South India to prevent the disease like Malaria and other infectious diseases arising during rainy season. Alstonia scholaris is observed to possess free-radical scavenging, antioxidant, anti-inflammatory, antimutagenic, and immunomodulatory activities. ${ }^{31}$

\section{Treatment principles as per Ayurvedic texts}

In Ayurveda Chikitsa is classified into 3 types Daivavyapashraya Chikitsa (divine therapy), Yuktivyapashraya Chikitsa (rational therapy) and Satvavajaya Chikitsa (psychotherapy). Daivavyapashraya Chikitsa involves measures to combat diseases caused by natural causes like floods, famine etc. Yuktivyapashraya is treatment based on fundamental principles of Ayurveda. Sattvavajaya Chikitsa is to control the mind by withdrawing it from undesired objects. ${ }^{32}$ It is equally important to have a positive outlook during the times of illness and distress. Hence, it is advised to decorate the house with flowers and illuminate the house, listen to pleasant soothing music or words and fill the mind with positivity. Though, it appears to be trivial, lighting of lamp implies dispelling darkness by light, so also ignorance by knowledge and fear by faith. Hence, most of the events in India commences with lighting of lamp as it is considered to be an auspicious event. Various measures are also described to cleanse the environment periodically. The terms HomaMani-Mantra etc have been described as different types of treatment, referred to as "Daiva vyapashraya" (treatment not by medicines but by invoking blessings from supernatural powers). For instance, during ancient times, fumigation measures were conducted in the pretext of religious offerings also known as Homa \& Agnihotras which yielded the benefits of reducing the microbial counts as well as fungal counts in the air.

\section{Conclusion}

While different treatments are being tried to manage Covid19 like antiviral drugs, hydroxychloroquine, plasma therapy and so on, isolation and containment remains best methods of prevention. Lack of effective therapeutics for the most of viral diseases, emergence of antiviral drug resistance, and high cost of some antiviral therapies necessitate finding new effective antiviral compounds. Hence, taking clues from above instances, it might be wise to adopt prophylactic and therapeutic strategies on the basis of Ayurveda. Acharya Sushrutha also known as Father of surgery opined that one should be open minded to imbibe the best of all systems of knowledge to get the finest possible results which implies a transdisciplinary action might save thousands of lives. Many Indian rituals and ceremonies end with prayers such as Lokāḥ Samastāḥ Sukhino Bhavantu, meaning "Let the entire world be happy." Sarve Jana sukhino Bhavantu. Let the People of the world be happy which is very relevant in this context.

\section{Acknowledgments}

Authors are thankful to Director General and Deputy Director General, CCRAS for their constant support and Dr. Chandini Nambiar and Dr.Sunona George for their timely help.

\section{Conflicts of interest}

Author declares that there are no conflicts of interest.

\section{Funding}

None.

\section{References}

1. Sharma H. Ayurveda: Science of life, genetics, and epigenetics. Ayu. 2016;37(2):87-91.

2. Agnivesha, Charaka Samhita, ayurveda deepika commentary. In: Vaidya Yadavji Trimkamji Acharya publication Choukhamba vishwabharati prakashan Varanasi. India; 2011. P. 241.

3. Shukla N. Ayurvedic approach to communicable disease -An overview. Open Access Scientific Reports. 2012;1:122.

4. Sushruta Samhita Niryansagar Publication. 1941. Sutra Sthana 21/37. 
5. Vaghbhata, Astanga Hrudaya, Sarvangasundara vyakhya uttarasthana 6/66 Chaukambha Sanskrit Sansthan. Varanasi; 2011.

6. Acharya Sushruta, Shushrutasamhita, Dwivraniyamadhyaya, Chikitsa Sthana, 1/8, p. 248 In: Priya Vrat Sharma, Varanasi, India: Chaukambha Vishvabharati; 2013.

7. Rajneesh V Giri. Shashti Upakrama (Sixty Procedures) in the management of Vrana (Wound) - A Review. J Res Tradit Med. 2017;3(4):109-116.

8. Vinay A Pawar. Pramana Vidnyana-An ancient method of research w. S. R. T. Charaka samhita vd. IAMJ: 2014;2(4):466.

9. Acharya YT. Chraka Samhita of Agnivesha, Sutra Sthana; Arthedashamahamuliya. Chapter 30, Version 26. Varanasi, India: Chaukhambha Orientalia; 2011. p. 187.

10. Tripathi JS, Singh RH. The Concept and Practice of Immunomodulation in Ayurveda and the Role of Rasayanas as Immunomodulators. Anc Sci Life. 1999;19(1-2):59-63.

11. Tillu G, Chaturvedi S, Chopra A, et al. Public Health Approach of Ayurveda and Yoga for COVID-19 Prophylaxis. The Journal of Alternative and Complementary Medicine. 2020;26(5):360-364.

12. Jakhar Y, Kaur J, Pathak A. A Review on Dinacharya. World Journal of Pharmaceutical and Medical Research. 2019;5(2):350-352.

13. Sudha VB, Ganesan S, Pazhani GP, et al. Storing drinking-water in copper pots kills contaminating diarrhoeagenic bacteria. $J$ Health Popul Nutr. 2012;30(1):17-21.

14. Thakkar J, Chaudhari S, Sarkar PK. Ritucharya: Answer to the lifestyle disorders. Ayu. 2011;32(4):466-471.

15. Mallika KJ. Critical study of Swastha-Catuska w.s.r. to Biophysical and Biochemical changes in Rtusandhi. MD (Ayu) Thesis. Jamnagar, India: Gujarat Ayurved University; 2002.

16. Nelson RJ, Demas GE. Seasonal changes in immune function. Q Rev Biol. 1996;71(4):511-548.

17. Nautiyala CS, Chauhana PS, Nene YL, Medicinal Smoke Reduces Airborne Bacteria. J Ethnopharmacol. 2007;114(3):446-451.

18. Devarajan A, Mohanmarugaraja MK. A Comprehensive Review on Rasam: A South Indian Traditional Functional Food. Pharmacogn Rev. 2017;11(22):73-82.
19. Soheil Zorofchian Moghadamtousi, Habsah Abdul Kadir. A Review on Antibacterial, Antiviral, and Antifungal Activity of Curcumin. Biomed Res Int. 2014;2014:186864.

20. Bryan C. Mouncea Teresa Cesaroa1 Lucia Carrauab ThomasValleta MarcoVignuzzia. Antiviral Research. 2017;142:148-157

21. Mehrbod P, Amini E, Tavassoti-Kheiri M. Antiviral activity of garlic extract on Influenza virus. Iranian J Virol. 2009;3(1):19-23.

22. Vaidya Bhagwan Dash. Materia Medica of Ayurveda. New Delhi, India: Concept Publishing; 1980.p. 54.

23. Abd El-Wahab A, El-Adawi H, El-Demellawy M. 24. In vitro study of the antiviral activity of Zingiber officinale. Planta Med. 2009;(75):PF7.

24. Neha S. Efficacy of Garlic and Onion against virus. Int J Res Pharm Sci. 201910(4):3578-3586.

25. Vagbhata, Ashtanga Hridaya. In: Srikantha Murthy K R, editor. Varanasi, India; Chowkamba Press; 1991.p. 11-12.

26. https://www.ayush.gov.in/docs/123.pdf

27. Charaka Samhita Niryansagar press Ch. Chi. $3 / 48$

28. https://healthyliving.natureloc.com/

29. Baliga MS. Alstonia scholaris Linn $\mathrm{R} \mathrm{Br}$ in the treatment and prevention of cancer: past, present, and future. Integr Cancer Ther. 2010;9(3):261269.

30. Dhanya T. Treatment of Manovikaras in Ayurveda. International Journal of Innovative Research in Medical Science. 2017;2(09):1268-1271.

31. Priyadarshini S, Harsha TS, Mythrey RC. Comparative Analysis of Bacterial and Fungal Counts in 'Vastu Homa, A Traditional air Purification Process. Paripex ${ }^{-}$Indian Journal of Research. 2017;6(2).

32. Priyadarshini S, Mythrey Harsha, Nabhiraj A. Sri narasimha homa -a comparitive study with special reference to seasons. Global Journal for Research Analysis. 2019;8(4).

33. https://www.abebooks.com/Inscriptions-Vijayanagara-Rulers-VolPart-1-5/773502045/bd 